\title{
Antifungal effect of organic acids from lactic acid bacteria on Penicillium nordicum
}

\author{
Ana Guimarães (1), Armando Venancio (1) and Luís Abrunhosa \\ CEB - Centre of Biological Engineering, University of Minho, Braga, Portugal
}

\begin{abstract}
The control of fungal contamination is particularly important to avoid both spoilage of food and feed products and the occurrence of toxic compounds, known as mycotoxins. Some lactic acid bacteria (LAB) strains have shown the capacity to inhibit fungal growth and the production of mycotoxins. In this work, cell-free supernatants (CFS) of Lactobacillus plantarum UM55 and Lactobacillus buchneri UTAD104 were tested against Penicillium nordicum radial growth and OTA production. When CFS of these strains were used, the radial growth of the fungus was inhibited by less than $20 \%$, but the production of OTA was reduced by approx. $60 \%$. These antifungal effects resulted from organic acids produced by LAB. The CFS of L. plantarum UM55 contained lactic acid, phenyllactic acid (PLA), hydroxyphenyllactic acid (OH-PLA) and indole lactic acid (ILA), while L. buchneri UTAD104 CFS contained acetic acid, lactic acid and PLA. These organic acids were further tested individually for their inhibitory capacity. Calculation of the inhibitory concentrations (ICS) showed that acetic acid, ILA and PLA were the most effective in inhibiting $P$. nordicum growth and OTA production. When the inhibitory activity of LAB cells incorporated into the culture medium was tested, L. buchneri UTAD104 inhibited the production of OTA entirely in all conditions tested, but fungal growth was only inhibited completely by the highest concentrations of cells. Acetic acid production was primarily responsible for this effect. In conclusion, the ability of LAB to inhibit mycotoxigenic fungi depends on strain capability to produce specific organic acids, and those acids may differ from strain to strain. Also, the use of LAB cells, especially from $L$. buchneri, in food products prone to contamination with $P$. nordicum (e.g. dry-cured meats and cheeses) may be an alternative solution to control fungal growth and OTA production.
\end{abstract}

\section{ARTICLE HISTORY}

Received 16 January 2018

Accepted 1 July 2018

\section{KEYWORDS}

OTA; Lactobacillus plantarum; Lactobacillus buchneri; Penicillium nordicum; lactic acid; phenyllactic acid; hydroxyphenyllactic acid; indole-lactic acid; acetic acid

\section{Introduction}

Contamination by certain moulds on food products renders them unfit for consumption when they are a source of undesirable health effects. In fact, fungal contamination is responsible for the loss of $5-10 \%$ of the world's food production (Pitt and Hocking 2009). Penicillium nordicum is a common contaminant of proteinaceous food and often found on drycured meat products, fish, cheese and jam (Lund and Frisvad 2003). This fungus is also the main OTA producer in dry-cured meat and has already been found in meat processing plants; thus, its control is crucial for the safety of these products (Bogs et al. 2006; Battilani et al. 2007; Sonjak et al. 2011). OTA has nephrotoxic, hepatotoxic, immunogenic and teratogenic effects even when ingested at low concentrations, and has been classified as a class II carcinogen (IARC 1993; Höhler 1998; FAO/WHO
2002; Petzinger and Weidenbach 2002). Because of its high stability, it's difficult to eliminate OTA from food products; thus, strategies for preventing this mycotoxin from entering the food chain should be focused primarily on inhibiting fungal growth and OTA production.

Physical and chemical methods in food preservation can be used to control the development of fungi in foods and consequently reduce their mycotoxins content; however, in many cases, they are impractical or ineffective (Brul and Coote 1999). In consequence, the search for more natural alternatives of food preservation is driving researchers to come up with biological methods to prevent fungal contamination and mycotoxin production. This strategy also meets consumers' demands for healthier and safer food.

One of these biological methods is biopreservation, which can be defined as the control of one

CONTACT Luís Abrunhosa luisjap@deb.uminho.pt Centro de Engenharia Biológica, Universidade do Minho, Campus de Gualtar, Braga 4710-057, Portugal

Color versions of one or more of the figures in this article can be found online at www.tandfonline.com/tfac.

(c) 2018 Taylor \& Francis Group, LLC 
organism by another (Magnusson et al. 2003). Lactic acid bacteria (LAB) are ideal candidates to be used as natural biopreservatives since they can have probiotic properties, which are beneficial to the host, and have been extensively used in fermentation processes (Naidu et al. 1999). Additionally, some LAB strains possess antifungal properties that result from a combination of factors, such as competitive growth, decrease in $\mathrm{pH}$ and the production of antifungal compounds, such as organic acids, proteinaceous compounds, fatty acids and bacteriocin-like substances (Niku-Paavola et al. 1999; Magnusson and Schnurer 2001; Ström et al. 2002; Sjögren et al. 2003; Rouse et al. 2008; Bianchini and Bullerman 2009). The most reported antifungal activity of LAB is generally associated with the production of organic acids, which results from the primary metabolism from carbohydrates fermentation. Numerous works have reported the production of organic acids with antifungal ability; mainly lactic and acetic acid, but also formic, propionic, butyric, phenyllactic, hydroxyphenyllactic acids, among others (Corsetti et al. 1998; Lavermicocca et al. 2000, 2003; Magnusson et al. 2003; Broberg et al. 2007; Gerez et al. 2009; Prema et al. 2010; Yang and Chang 2010; Rizzello et al. 2011; Özcelik et al. 2016; Guimarães et al. 2018b). Production of organic acids lowers the $\mathrm{pH}$ of the media and creates adverse conditions for the growth of potentially pathogenic microorganisms in food products and human intestinal microflora (Ammor et al. 2006).

Still, just a few reports describe the influence of these acids in the production of mycotoxins (Sangmanee and Hongpattarakere 2014; Oliveira et al. 2015). This work aims to demonstrate the potential of LAB and their organic acids to control the growth of $P$. nordicum as well as the production of OTA.

\section{Materials and methods}

\section{Biological materials and growth conditions}

P. nordicum MUM 08.16 (CBS 112573) was revived in YES agar in the dark at $25^{\circ} \mathrm{C}$. YES agar formulation consisted in $150 \mathrm{~g} \mathrm{~L}^{-1}$ of sucrose, $20 \mathrm{~g} \mathrm{~L}^{-1}$ of yeast extract, $15 \mathrm{~g} \mathrm{~L}^{-1}$ of agar, $0.5 \mathrm{~g} \mathrm{~L}^{-1}$ of $\mathrm{MgSO}_{4}, 0.01 \mathrm{~g} \mathrm{~L}^{-1}$ of $\mathrm{ZnSO}_{4}$ and $0.005 \mathrm{~g} \mathrm{~L}^{-1}$ of $\mathrm{CuSO}_{4}$. After 7 days of growth, fungal spores were suspended in a $0.1 \%$ peptone solution with $0.05 \%$ Tween 80 (Fisher Chemical). To determine the concentration of spores in the inocula, spores were counted in a microscope using a Neubauer cell chamber. Spore concentration was adjusted to $10^{6}$ spores $\mathrm{mL}^{-1}$, and aliquots of spore solutions were stored at $-20^{\circ} \mathrm{C}$ for the duration of experimental work. Lactobacillus plantarum UM55 and Lactobacillus buchneri UTAD104 were isolated from milk and silage, respectively, and were stored in glycerol stocks in our private collection. Strains were molecularly identified by STAB VIDA laboratory, Portugal. The amplification of $16 \mathrm{~S}$ rDNA from the bacterial strains was performed with the primers 27F (5'-AGAATTTGATCMTGGCTCAG-3') and 149 2R (5'-TACGGYTACCTTGTTACGACTT-3'). The PCR products of $16 \mathrm{~S}$ rDNA were sequenced, obtained sequences were aligned with sequences in the Genbank database and the percentage of homology was determined. The $16 \mathrm{~S}$ rRNA sequences of both strains were deposited in GenBank under the accession numbers: MG786718 for L. plantarum UM55 and MG786678 for L. buchneri UTAD104.

\section{Characterisation of antifungal properties of CFS from $L A B$ strains}

L. plantarum UM55 and L. buchneri UTAD104 were previously selected for their antifungal activity using a 'dual-culture overlay assay' (data not shown) (Magnusson and Schnurer 2001). To establish their antifungal ability against $P$. nordicum MUM 08.16, these strains were tested using the 'poisoned food technique' (Balouiri et al. 2016). Briefly, LAB were cultivated in MRS broth (Oxoid) supplemented with $20 \%$ of tomato juice (Fluka) and $1 \mathrm{~g} \mathrm{~L}^{-1}$ of cysteine (Fisher Chemical), at $30^{\circ} \mathrm{C}$ for 2 days. The cell cultures were then centrifuged (10 min at 7000 relative centrifugal force (RCF)), cell pellets were discarded and the resulting supernatants were sterilised by filtration through a $0.2-\mu \mathrm{m}$ pore size sterile filter (CA-S, Whatman). Then, $10 \%(\mathrm{v} / \mathrm{v})$ of the cell-free supernatant (CFS) was added to YES agar medium poured into Petri plates. After cooling down, the plates were inoculated, in the centre, with $10 \mu \mathrm{L}$ of the fungal spore suspension $\left(10^{6}\right.$ spores $\left.\mathrm{mL}^{-1}\right)$. Control experiments were prepared by adding MRS broth, instead of the CFS. Plates were incubated for 7 days at $25^{\circ} \mathrm{C}$ in the dark. Two 
perpendicular diameters of the growing fungal colonies were measured daily, and OTA content was extracted after 7 days of growth. All experiments were done in triplicate.

The nature of the potential antifungal compounds present in the CFS was determined by subjecting L. plantarum UM55 and L. buchneri UTAD104 CFS to heat, proteases treatments and neutralisation of $\mathrm{pH}$. To evaluate if heat compromised the antifungal ability of CFS, one fraction of CFS was exposed to $121^{\circ} \mathrm{C}$ for $20 \mathrm{~min}$. To evaluate if proteases inactivated CFS compounds, another fraction of CFS was exposed to pepsin (Amresco) at a concentration of $2 \mathrm{mg} \mathrm{mL}^{-1}$. Following the addition of the protease, CFS was incubated at $37^{\circ}$ $\mathrm{C}$ for $3 \mathrm{~h}$ and then filtered again. To evaluate the effect of $\mathrm{pH}$ neutralisation in antifungal activity, the $\mathrm{pH}$ of CFS was adjusted to 7 with the addition of $1 \mathrm{M} \mathrm{NaOH}$. The antifungal activity of CFS subjected to the above-described treatments was determined by the 'poisoned food technique' as described above.

\section{High-performance liquid chromatography (HPLC) analysis of CFS}

Extraction of organic acids from LAB CFS was conducted following a protocol adapted from Brosnan et al. (2014). Briefly, $10 \mathrm{~mL}$ of the CFS obtained as previously described were added to $10 \mathrm{~mL}$ of ethyl acetate (VWR) with $1 \%$ formic acid (Sigma-Aldrich), $4 \mathrm{~g}$ of magnesium sulphate (Sigma-Aldrich) and $1 \mathrm{~g}$ of sodium chloride (VWR). The mixture was homogenised by vortexing for $1 \mathrm{~min}$ and then centrifuged for $10 \mathrm{~min}$ at 3000 RCF. A 5-mL portion of the top fraction (containing the organic solvent) were then collected and added to $100 \mu \mathrm{L}$ of dimethyl sulfoxide (VWR). The resultant solution was evaporated under nitrogen and reconstituted to $1 \mathrm{~mL}$ with $\mathrm{H}_{2} \mathrm{O} /$ acetonitrile $(90 / 10, \mathrm{v} / \mathrm{v})$. The solution was filtered through a $0.45-\mu \mathrm{m}$ syringe filter (Nylon, Whatman) into HPLC amber vials. Unfermented MRS broth was used as the control and extracted under the same conditions.

The HPLC used to detect and quantify organic acids was a Shimadzu Nexera LC system with a photodiode array detector (SPD-M20A). The chromatographic separation was performed on a Brisa
$\mathrm{LC}^{2} \mathrm{C}_{18}$ column $(250 \mathrm{~mm} \times 4.6 \mathrm{~mm}$ I.D., $5 \mu \mathrm{m}$, Teknokroma) that was fitted with a precolumn with the same stationary phase. The organic acids were eluted under gradient conditions using $\mathrm{H}_{2} \mathrm{O}$ with $0.1 \%$ formic acid (solvent $\mathrm{A}$ ) and acetonitrile with $0.1 \%$ formic acid (solvent B). Both solvents were filtered and degassed before use. The following gradient was used: $0 \mathrm{~min}-5 \% \mathrm{~B} ; 9 \mathrm{~min}-10 \% \mathrm{~B} ; 16 \mathrm{~min}$ - 30\% B; $32 \mathrm{~min}-30 \% \mathrm{~B} ; 48 \mathrm{~min}-40 \% \mathrm{~B} ; 56 \mathrm{~min}$ $40 \% \mathrm{~B} ; 65 \mathrm{~min}-95 \% \mathrm{~B} ; 73 \mathrm{~min}-95 \% \mathrm{~B} ; 80 \mathrm{~min}-$ $95 \%$. The flow rate was set to $1 \mathrm{~mL} \min ^{-1}$, the temperature to $30^{\circ} \mathrm{C}$ and a volume of $20 \mu \mathrm{L}$ was injected. Organic acids were detected at an ultraviolet (UV) wavelength of $210 \mathrm{~nm}$. Chromatographic data were analysed with the software LabSolutions version 5.71 (Shimadzu Corporation).

Stock solutions of each organic acid tested were prepared individually by dissolving the compounds in ultrapure $\mathrm{H}_{2} \mathrm{O}$. Calibration curves with 7 points were prepared at concentrations of $0.1-2 \mathrm{mg} \mathrm{mL}^{-1}$ for phenyllactic acid; of 1-20 $\mathrm{mg} \mathrm{mL}^{-1}$ for lactic acid; of $0.01-0.5 \mathrm{mg} \mathrm{mL}^{-1}$ for hydroxyphenyllactic acid $(\mathrm{OH}-$ PLA); and of $0.01-0.15 \mathrm{mg} \mathrm{mL}^{-1}$ for indole lactic acid (ILA). Organic acids were quantified by comparing the peak areas with the calibration curves.

\section{Antifungal properties of individual organic acids produced by $L A B$}

Organic acids tested for antifungal properties were selected because they were produced by LAB strains UM55 and UTAD104. These organic acids were tested individually for the inhibition of fungal growth and OTA production in P. nordicum MUM 08.16. Selected organic acids were lactic acid (Fluka), acetic acid (Fisher Scientific), phenyllactic acid (PLA; Acros Organics), OH-PLA (Sigma-Aldrich) and ILA (Sigma-Aldrich). Similarly to the previous experiment, organic acids were added to YES agar at $10 \%(\mathrm{v} / \mathrm{v})$ concentration, achieving final concentrations in the culture medium of $0.1,0.25,0.5,1.0,2.0$, 4.0 and $8.0 \mathrm{mg} \mathrm{mL}^{-1}$. Petri plates were incubated for 7 days, at $25^{\circ} \mathrm{C}$ in the dark. Fungal colony diameters were measured daily, and OTA contents analysed at the end of the experiment. Organic acids concentrations which inhibited by $50 \%\left(\mathrm{IC}_{50}\right)$ and $90 \%\left(\mathrm{IC}_{90}\right)$ the fungal growth and OTA production, were derived from non-linear fit of Log doses versus normalised inhibitions against a four-parameter 
logistic model (Hill equation) using the software GraphPad Prism version 7.02 for Windows (GraphPad Software, USA).

\section{Antifungal properties of $L A B$ cells}

The antifungal ability of $L$. plantarum UM55 and $L$. buchneri UTAD104 cells were, as well, tested by 'poisoned food technique'. Isolates from both strains were grown in MRS supplemented with tomato juice and $1 \mathrm{~g} \mathrm{~L}^{-1}$ of cysteine, for 2 days at $30^{\circ} \mathrm{C}$. Cells were centrifuged at $7000 \mathrm{RCF}$ for $10 \mathrm{~min}$, and the supernatant was discarded. The bacterial pellet was resuspended in PBS prepared as follows: $8 \mathrm{~g}$ of $\mathrm{NaCl}, 0.2 \mathrm{~g}$ of $\mathrm{KCl}, 1.44 \mathrm{~g}$ of $\mathrm{Na}_{2} \mathrm{HPO}_{4}$ and $0.24 \mathrm{~g}$ of $\mathrm{KH}_{2} \mathrm{PO}_{4}$ were added to $1 \mathrm{~L}$ of distilled water, and the final $\mathrm{pH}$ was set to 7.4. The number of cells per millilitre was standardised by measuring optical density (OD) at $600 \mathrm{~nm}$. Suspensions of cells in PBS with ODs of 1, 2.5 and 5 were prepared. Cells suspensions in PBS were incorporated into YES agar at the proportion of $10 \%(\mathrm{v} /$ v) and poured into plates. Then plates were inoculated by dropping $10 \mu \mathrm{L}$ of the $P$. nordicum spore suspension $\left(10^{6}\right.$ spores $\left.\mathrm{mL}^{-1}\right)$ in the centre of the plate. In the control experiments, PBS replaced cells suspensions. Again, plates were incubated for 7 days at $25^{\circ} \mathrm{C}$ in the dark. Diameters of the growing fungal colonies were measured daily. OTA was extracted after 7 days of growth as described below. All experiments were done in triplicate.

\section{HPLC analysis of lactic and acetic acid extracted from plates containing $L A B$ cells}

Organic acids were determined in the solid medium (YES agar) incorporated with $L$. plantarum UM55 and L. buchneri UTAD104 cells, and PBS (control), as stated in the previous section. After 7 days of incubation, plates were cut and placed in a tube with $20 \mathrm{~mL}$ of distilled water. Tubes were vortexed vigorously and left overnight. Solutions were filtered through a $0.22-\mu \mathrm{m}$ syringe filter (PES, Whatman) into vials and analysed by HPLC with UV detection. An HPLC method adapted from datasheet T910226A from YMC Separation Technology was used to determine lactic and acetic acid in samples. The HPLC system consisted of a Varian Prostar 210 pump, a Varian
Prostar 410 autosampler and a Varian ProStar 325 UV-Vis detector. The interface between HPLC system and computer was established by a Varian 850-MIB data system, and Galaxie software managed chromatographic data. $\mathrm{A}_{18}$ reversedphase YMC-Pack ODS-AQ analytical column $(250 \mathrm{~mm} \times 4.6 \mathrm{~mm}$ I.D., $5 \mu \mathrm{m})$ was used for the chromatographic separation. The mobile phase was a solution of $10 \mathrm{mM}$ of $\mathrm{NaH}_{2} \mathrm{PO}_{4}$ and $10 \mathrm{mM}$ of $85 \% o$-phosphoric acid, and the $\mathrm{pH}$ was set to 2.8 with $1 \mathrm{M}$ of $\mathrm{NaOH}$. The mobile phase was filtered with a $0.45-\mu \mathrm{m}$ membrane filter (MCE, Whatman) and sonicated for $20 \mathrm{~min}$. Chromatographic runs were of $50 \mathrm{~min}$ with a flow rate of $0.7 \mathrm{~mL} \mathrm{~min}{ }^{-1}$. The injection volume was $20 \mu \mathrm{L}$, and the temperature was set to $30^{\circ} \mathrm{C}$. Detection of organic acids was made at a wavelength of $220 \mathrm{~nm}$. Calibration curves were made with standards of lactic and acetic acids in distilled water with a concentration of $0.5-20 \mathrm{mg} \mathrm{mL}^{-1}$ and 1-50 $\mathrm{mg} \mathrm{mL}^{-1}$, respectively.

\section{OTA extraction and HPLC analysis}

OTA was extracted according to Guimarães et al. (2018b). Briefly, after 7 days of incubation, all the content of the Petri plate was cut and placed in falcon tubes. A solution of acetonitrile/methanol/ acetic acid $(78 / 10 / 2, \mathrm{v} / \mathrm{v} / \mathrm{v})$ was added $(30 \mathrm{~mL})$, and the falcons were subjected to vigorous vortexing to extract the mycotoxin. Extracts were placed in the dark at room temperature overnight. The content of the falcons was then filtered using $0.45 \mu \mathrm{m}$ syringe filters (nylon, Whatman) into amber vials and analysed by HPLC and fluorescence detection with previously implemented methods (Calado et al. 2018). The HPLC system used was the same described in the previous section but connected to a Jasco FP-920 fluorescence detector $\left(\lambda_{\text {exc }}=333 \mathrm{~nm}\right.$ and $\left.\lambda_{\mathrm{em}}=460 \mathrm{~nm}\right)$. The column used to perform chromatographic separation was a $\mathrm{C}_{18}$ reversed-phase YMC-Pack ODS-A analytical column $(250 \mathrm{~mm} \times$ $4.6 \mathrm{~mm}$ I.D., $5 \mu \mathrm{m}$ ) that was protected by a precolumn with the same stationary phase. The mobile phase used to elute OTA was a mixture of water/ acetonitrile/acetic acid (99/99/2, v/v/v) that was previously filtered with $0.2-\mu \mathrm{m}$ membrane filter (GHP, Gelman) and degassed for $20 \mathrm{~min}$. The flow rate was set to $1.0 \mathrm{~mL} \mathrm{~min}{ }^{-1}$ for a $15-\mathrm{min}$ isocratic run, and 
the injection volume was $50 \mu \mathrm{L}$. Calibration curves were created using a certified OTA standard solution (CRM46912, Sigma-Aldrich) at concentrations

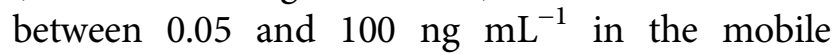
phase. The concentration of OTA was obtained by comparing peak areas with the calibration curves.

\section{Data analysis}

Three independent replicates were performed in all experiments and results were expressed as mean values \pm standard deviation. Data were compared by analysis of variance (ANOVA) with Tukey's multiple comparisons test at $p<0.05$ using the software GraphPad Prism version 7.02 for Windows (GraphPad Software, USA).

\section{Results}

\section{Characterisation of antifungal properties of CFS from $L A B$ strains}

The inhibitory effects of CFS from $L$. plantarum UM55 and L. buchneri UTAD104 on the growth of P. nordicum MUM 08.16 were weak since reductions of only $17 \%$ and $10 \%$ were reached, respectively. Nonetheless, the effects on OTA production were considerably higher; inhibitions were achieved of $63 \%$ and $61 \%$ for L. plantarum UM55 and L. buchneri UTAD104 CFS, respectively.

CFS were further subjected to treatments by heat, proteases and $\mathrm{pH}$ neutralisation, in order to determine the nature of the compounds responsible for the antifungal activity. It was observed that both L. plantarum UM55 and L. buchneri UTAD104 CFS retained their inhibitory properties after being autoclaved and treated with proteases, but not after the $\mathrm{pH}$ neutralisation (Figure 1). Results showed that L. plantarum UM55 CFS treated with pepsin and heat reduced fungal colony size, respectively, in $16 \%$ and $24 \%$, and OTA production in approx. $57 \%$ and $53 \%$, respectively. Similar results were obtained with $L$. buchneri UTAD104 CFS. Inhibition values for both of these treatments were not significantly different from inhibition caused by untreated CFS, showing that they were not able to eliminate CFS effects. However, for both LAB strains, the CFS that was submitted to $\mathrm{pH}$ neutralisation lost its antifungal activity. The growth of fungi achieved similar values to MRS control and OTA produced by the colonies increased.

Because the $\mathrm{pH}$ greatly influenced the CFS activity of these strains, it was hypothesised that organic acids could be responsible for the antifungal effect observed. In following experiments, CFS at $\mathrm{pH} 7$ were used as the control because antifungal effects were eliminated when CFS was neutralised.

\section{Antifungal properties of individual organic acids produced by $L A B$}

Since it was observed that neutralisation of CFS reverted its anti-ochratoxigenic effect, the presence of organic acids in CFS of L. plantarum UM55 and L. buchneri UTAD104 was investigated by HPLC. Organic acid profiles of both LAB were compared with MRS broth. Main differences in HPLC chromatograms between $L$. plantarum UM55 and MRS control were detected at retention times corresponding to peaks of lactic acid, $\mathrm{OH}$ PLA, PLA and ILA. In the case of L. buchneri UTAD104, differences between CFS and controls were found in lactic acid and PLA. In MRS broth, none of these acids was detected (Figure 2 and Table 1). Also, acetic acid could not be detected by this method, though it is known that L. buchneri is a producer of this acid (Holzer et al. 2003).

Next, the antifungal properties of these acids were tested individually using the 'food poisoning' method. An example of the fungal colonies obtained in this experiment can be seen in Figure 3. Overall, all tested acids were able to inhibit to some extent the fungal growth and OTA production. However, the minimum concentration at which they had their maximum effect was different for each one. All tested organic acids inhibited production of OTA to a greater extent than fungal growth. Acetic acid and PLA were able to produce total inhibition of fungal growth at concentrations of 2 and $8 \mathrm{mg}$ $\mathrm{mL}^{-1}$, respectively. Lactic acid, OH-PLA and ILA produced an inhibition of approx. 50\% in fungal growth at the maximum tested concentration $\left(8 \mathrm{mg} \mathrm{mL}^{-1}\right)$.

Concerning the production of OTA, an inhibition of $100 \%$ was achieved with $2 \mathrm{mg} \mathrm{mL}^{-1}$ of acetic acid, $8 \mathrm{mg} \mathrm{mL}{ }^{-1}$ of PLA and $4 \mathrm{mg} \mathrm{mL}^{-1}$ of ILA. Maximum inhibitions obtained with lactic acid and 
$1 \mathrm{a}$

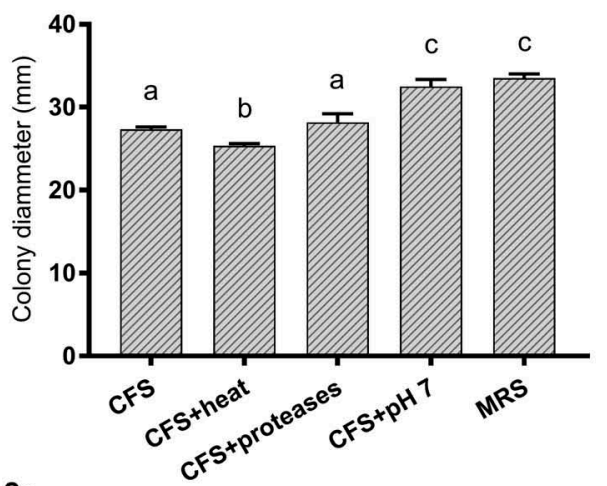

$2 a$

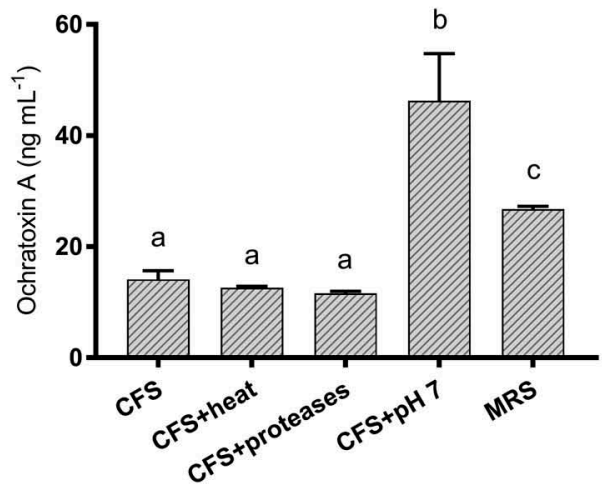

1b

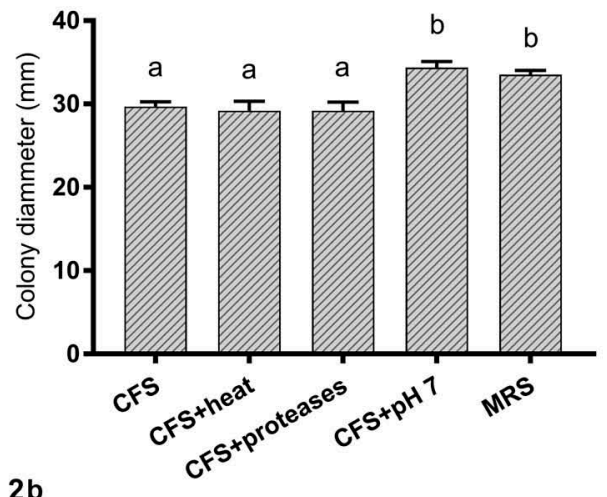

2b

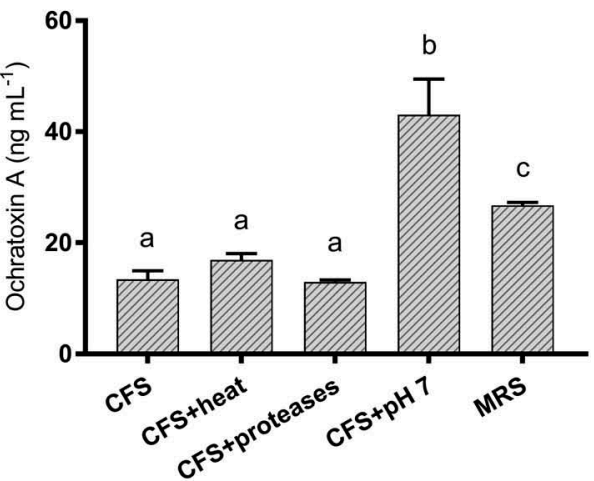

Figure 1. Effect of CFS from L. plantarum UM55 (A) and L. buchneri UTAD104 (B) on fungal growth (1) and OTA production (2) of $P$. nordicum MUM 08.16. Error bars indicate a standard deviation of $n=3$. Statistically significant differences for each condition are indicated with different letters, $p<0.05$ (one-way ANOVA and Tukey's post-hoc test).

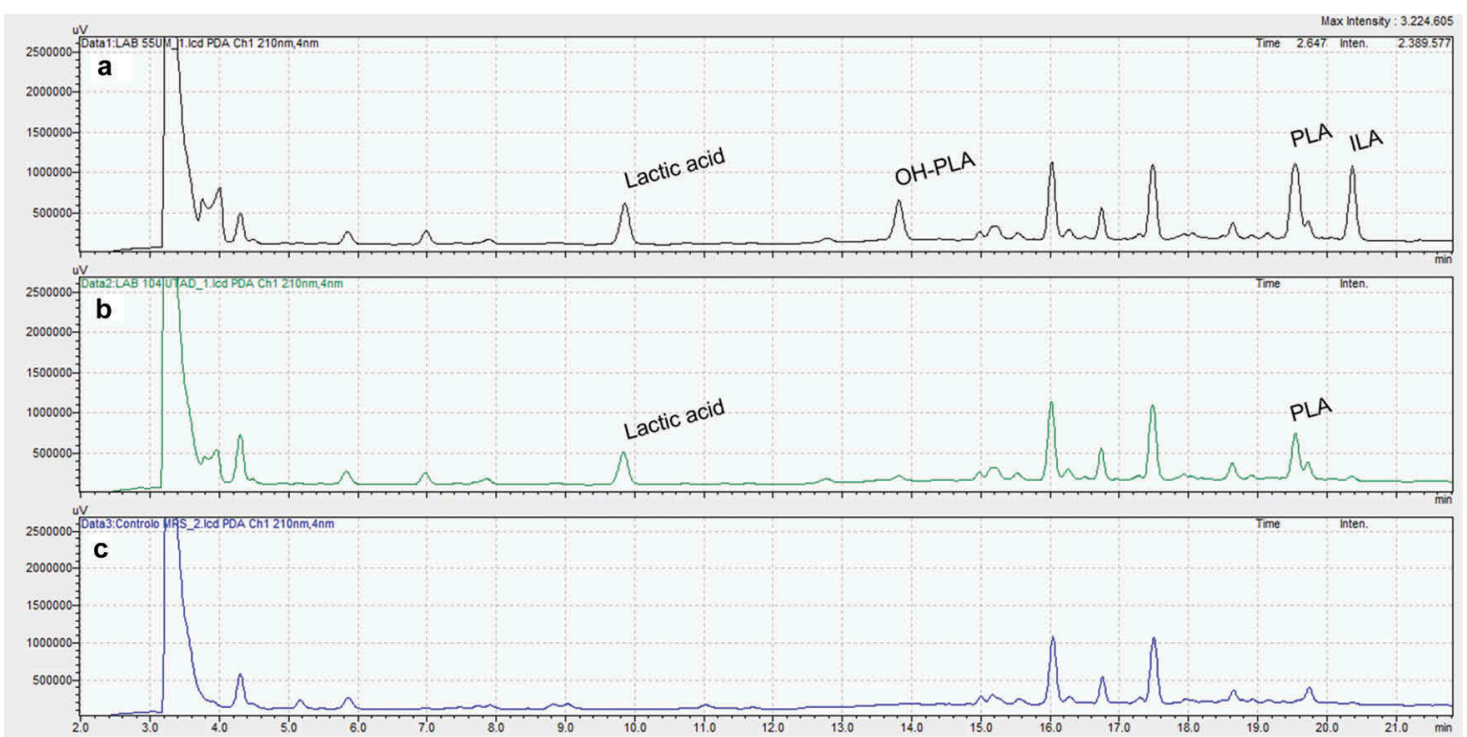

Figure 2. Chromatograms of L. plantarum UM55 CFS (A), L. buchneri UTAD104 CFS (B) and MRS broth (C).

OH-PLA were $60 \%$ and $72 \%$, respectively, at a concentration of $8 \mathrm{mg} \mathrm{mL}^{-1}$. The $\mathrm{pH}$ values of the culture media in which maximum OTA inhibition was achieved were 4.5, 3.7, 4.6, 3.6 and 3.7, for acetic acid $\left(2 \mathrm{mg} \mathrm{mL}^{-1}\right)$, PLA $\left(8 \mathrm{mg} \mathrm{mL}^{-1}\right)$, ILA $(4 \mathrm{mg}$ $\left.\mathrm{mL}^{-1}\right)$, lactic acid $\left(8 \mathrm{mg} \mathrm{mL}^{-1}\right)$ and OH-PLA (8 $\mathrm{mg}$ $\left.\mathrm{mL}^{-1}\right)$, respectively. In summary, the stronger effects were obtained with acetic acid, PLA and ILA. 
Table 1. Concentration of lactic acid, PLA, OH-PLA and ILA present in L. plantarum UM55 CFS, L. buchneri UTAD104 CFS and MRS broth.

\begin{tabular}{lcccc}
\hline & $\begin{array}{c}\text { Lactic acid (g } \\
\left.\mathrm{L}^{-1}\right)\end{array}$ & $\begin{array}{c}\text { PLA (mg } \\
\left.\mathrm{L}^{-1}\right)\end{array}$ & $\begin{array}{c}\text { OH-PLA }(\mathrm{mg} \\
\left.\mathrm{L}^{-1}\right)\end{array}$ & $\begin{array}{c}\text { ILA }(\mathrm{mg} \\
\left.\mathrm{L}^{-1}\right)\end{array}$ \\
\hline $\begin{array}{l}\text { L. plantarum UM55 } \\
\text { CFS }\end{array}$ & $4.3 \pm 0.2$ & $74.8 \pm 0.4$ & $30.8 \pm 1.5$ & $6.7 \pm 0.1$ \\
$\begin{array}{l}\text { L. buchneri } \\
\begin{array}{l}\text { UTAD104 CFS } \\
\text { MRS broth }\end{array}\end{array}$ & $3.4 \pm 0.1$ & $48.1 \pm 2.2$ & 0 & 0.6 \\
\hline
\end{tabular}

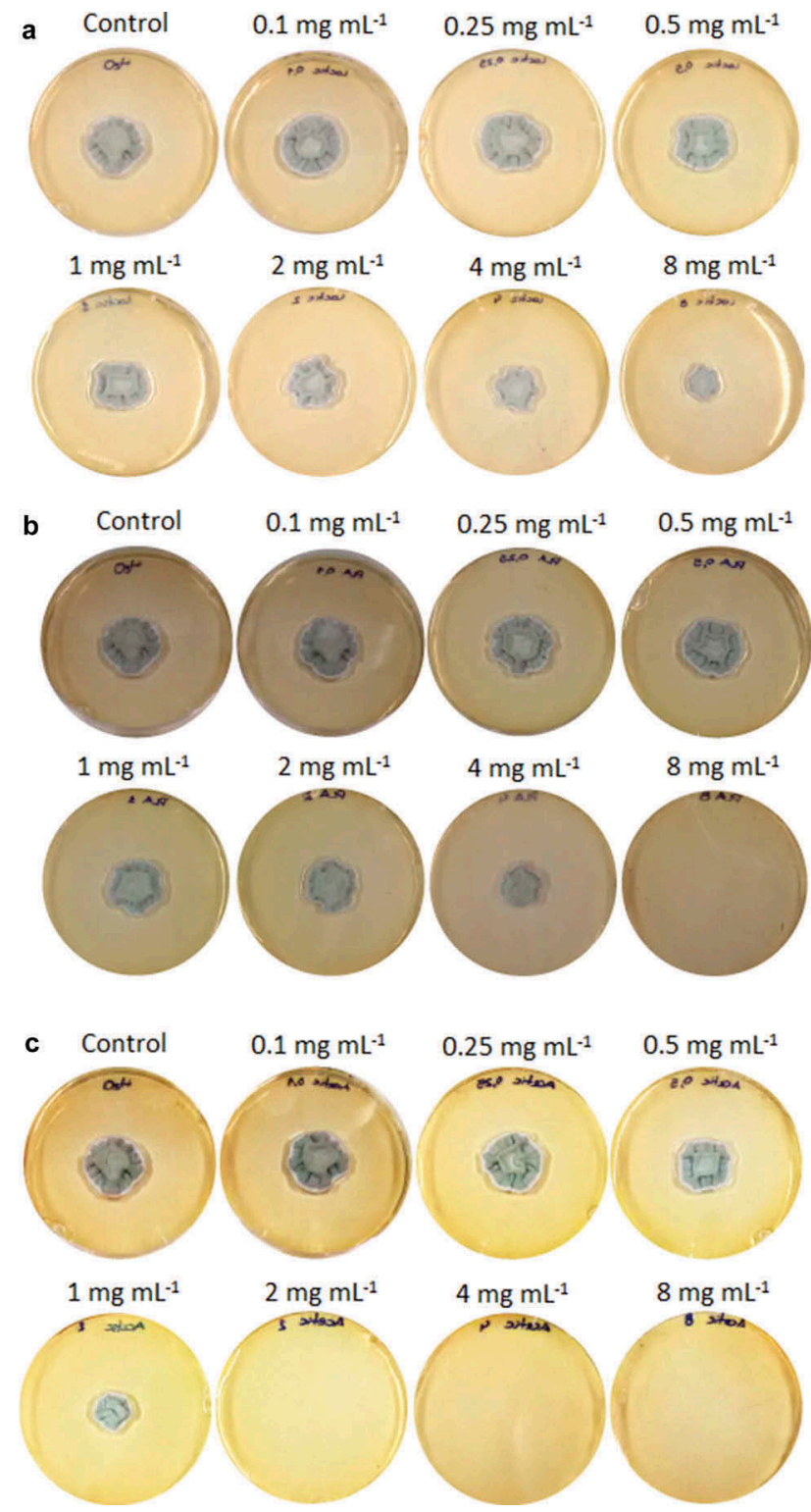

Figure 3. Example of the inhibition of $P$. nordicum growth by lactic acid (A), PLA (B) and acetic acid (C) determined by the 'poisoned food technique'.

$\mathrm{IC}_{50}$ and $\mathrm{IC}_{90}$ were calculated for each organic acid and are shown in Table 2. Concerning fungal growth, $\mathrm{IC}_{50}$ values of the selected acids were (in ascending order) acetic acid $\left(1.6 \mathrm{mg} \mathrm{mL}^{-1}\right)$, ILA
(3.6 mg mL $\mathrm{mg}^{-1}$ ), PLA (4.4 $\left.\mathrm{mg} \mathrm{mL}^{-1}\right)$, lactic acid (7.4 $\mathrm{mg} \mathrm{mL}^{-1}$ ) and OH-PLA $\left(8.9 \mathrm{mg} \mathrm{mL}^{-1}\right)$. The calculated values for $\mathrm{IC}_{90}$ followed the same tendency, with IC $_{90}$ for acetic acid, ILA, PLA, lactic acid and OH-PLA being 1.7, 8.2, 8.4, 58.4 and $68.1 \mathrm{mg} \mathrm{mL}^{-1}$, respectively.

Concerning OTA, the lowest $\mathrm{IC}_{50}$ was obtained for ILA $\left(1.2 \mathrm{mg} \mathrm{mL}^{-1}\right)$, followed by PLA $(1.3 \mathrm{mg}$ $\left.\mathrm{mL}^{-1}\right)$, acetic acid $\left(1.6 \mathrm{mg} \mathrm{mL} \mathrm{m}^{-1}\right)$, OH-PLA $\left(1.7 \mathrm{mg} \mathrm{mL}{ }^{-1}\right)$ and lactic acid $\left(2.9 \mathrm{mg} \mathrm{mL}^{-1}\right)$. Except for lactic acid, all acids showed similar concentrations at which they produced an inhibition of approx. $50 \%$ in OTA production. Results of $\mathrm{IC}_{90}$ showed a different tendency. Acetic acid presented the lowest value $\left(1.7 \mathrm{mg} \mathrm{mL}{ }^{-1}\right)$, followed by ILA and PLA (3.2 and $4.5 \mathrm{mg} \mathrm{mL}^{-1}$, respectively), and OH-PLA and lactic acid with a considerably higher concentration (13.1 and $45.9 \mathrm{mg} \mathrm{mL}^{-1}$, respectively).

When comparing ICs values for growth and OTA inhibition, acetic acid showed the highest inhibition of $P$. nordicum MUM 08.16. From the ICs obtained, it can also be observed that lactic acid is the least effective of the organic acids in inhibiting the production of OTA, and one of the least effective (after OH-PLA) in inhibiting fungal growth.

\section{Antifungal properties of LAB cells}

Besides the effects observed with CFS of L. plantarum UM55 and L. buchneri UTAD104, viable LAB cells of these strains have also shown antifungal ability (Figure 4). The incorporation of viable cells in culture media resulted in situ production of antifungal compounds, increasing the antifungal potential of these biocontrol agents. L. plantarum UM55 and L. buchneri UTAD104 cells were very effective in inhibiting both growth and OTA production of $P$. nordicum MUM 08.16 when they were incorporated into YES culture medium. At $\mathrm{OD}=5$, the strain $L$. plantarum UM55 inhibited fungal growth by $93 \%$ and the production of OTA by $100 \%$, while L. buchneri UTAD104 completely prevented the fungus from growing; consequently no OTA was produced. With an OD of 2.5, the addition of L. buchneri UTAD104 to the medium continued to produce the total inhibition of $P$. nordicum and production of OTA, while the addition of $L$. plantarum UM55 resulted in inhibitions of only $70 \%$ and $84 \%$ for fungal growth and 
Table 2. Inhibitory concentrations $\left(\mathrm{IC}_{50}\right.$ and $\mathrm{IC}_{90}$ in $\left.\mathrm{mg} \mathrm{mL}^{-1}\right)$ of lactic acid, PLA, OH-PLA, ILA and acetic acid against $P$. nordicum MUM 08.16.

\begin{tabular}{|c|c|c|c|c|c|c|}
\hline & \multicolumn{3}{|c|}{ Fungal growth } & \multicolumn{3}{|c|}{ OTA production } \\
\hline & $\mathrm{IC}_{50}\left(\mathrm{mg} \mathrm{mL}^{-1}\right)(95 \% \mathrm{Cl})$ & $\mathrm{IC}_{90}\left(\mathrm{mg} \mathrm{mL}^{-1}\right)(95 \% \mathrm{Cl})$ & $R^{2}$ & $\mathrm{IC}_{50}\left(\mathrm{mg} \mathrm{mL}^{-1}\right)(95 \% \mathrm{Cl})$ & $\mathrm{IC}_{90}\left(\mathrm{mg} \mathrm{mL}^{-1}\right)(95 \% \mathrm{Cl})$ & $R^{2}$ \\
\hline Lactic acid & $7.4(6.4-8.5)$ & $58.4(40.8-87.0)$ & 0.9845 & $2.9(2.3-3.8)$ & $45.9(24.1-98.6)$ & 0.9561 \\
\hline PLA & $4.4(3.7-4.9)$ & $8.4(6.2-12.3)$ & 0.9621 & $1.3(1.2-1.4)$ & $4.5(3.6-5.8)$ & 0.9838 \\
\hline OH-PLA & $8.9(7.8-10.4)$ & $68.1(48.3-98.8)$ & 0.9868 & $1.7(1.3-2.2)$ & $13.1(6.8-19.4)$ & 0.9346 \\
\hline ILA & $3.6(3.3-3.9)$ & $8.2(6.9-9.9)$ & 0.9852 & $1.2(1.0-1.4)$ & $3.2(2.4-4.5)$ & 0.9599 \\
\hline Acetic acid & $1.6(1.5-1.7)$ & $1.7(1.5-1.9)$ & 0.9854 & $1.6(1.4-1.8)$ & $1.7(1.6-1.8)$ & 0.9918 \\
\hline
\end{tabular}

$\mathrm{IC}_{50}$, concentration of organic acid which produced an inhibition of $50 \%$; $\mathrm{IC}_{90}$, concentration of organic acid which produced an inhibition of $90 \%$; $95 \% \mathrm{Cl}$, confidential interval of calculated values; $R^{2}$, R-square of fitted curves.
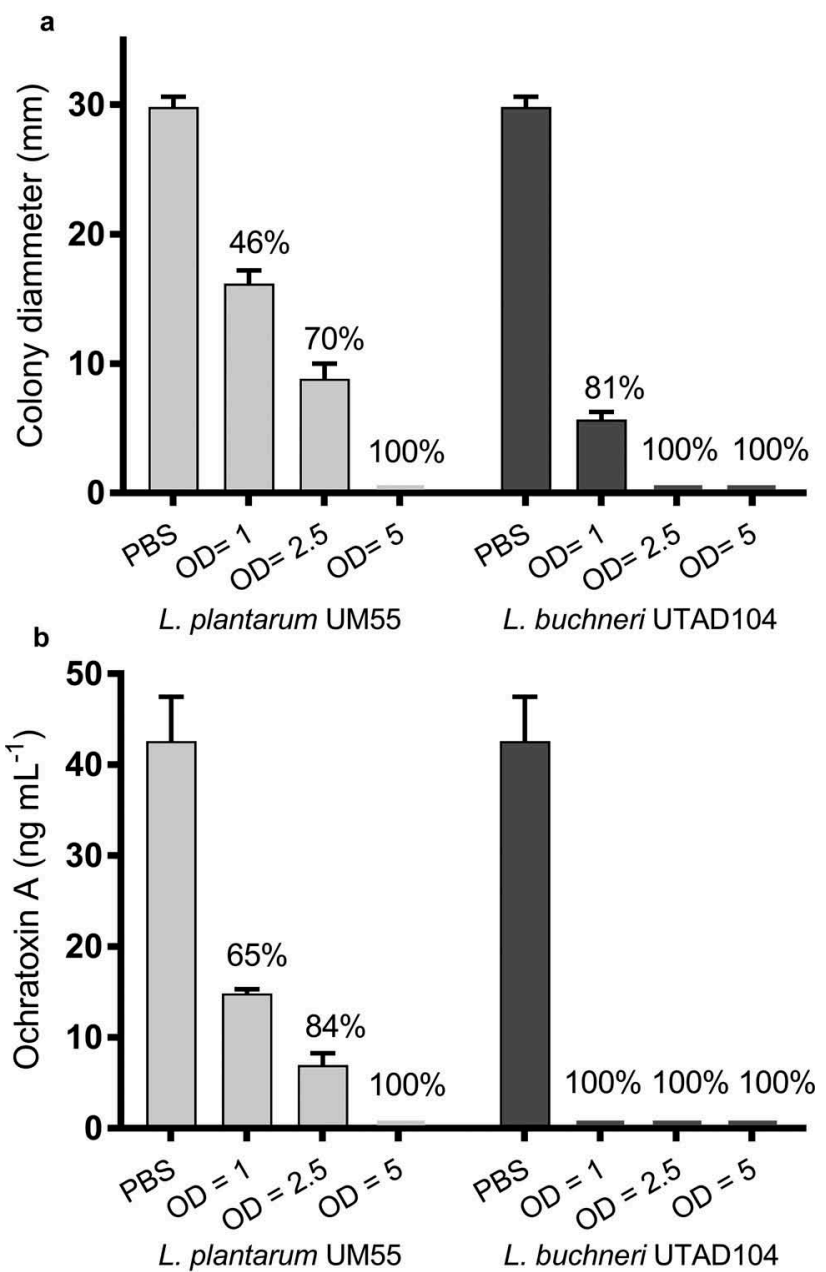

Figure 4. Fungal growth (A) and OTA production (B) of $P$. nordicum in YES media incorporating suspensions of cells of $L$. plantarum UM55 and L. buchneri UTAD104 with OD values of 1, 2.5 and 5. Error bars indicate a standard deviation of $n=3$. The percentages express the inhibition of growth and OTA production relatively to control experiments conducted with PBS.

OTA production, respectively. As expected a lower cell concentration, $\mathrm{OD}=1$, resulted in lower inhibitions for L. plantarum UM55, resulting in inhibitions of $46 \%$ and $65 \%$, for fungal growth and OTA production, respectively. For L. buchneri UTAD104, antifungal activity of $\mathrm{OD}=1$ remained high with the inhibition of growth reaching $81 \%$, which resulted in no production of OTA.

\section{Organic acids extracted from plates containing $L A B$ cells}

The quantities of organic acids produced in YES agar plates by L. plantarum UM55 and L. buchneri UTAD104 cells were analysed to determine the contents of acetic and lactic acids. Results can be seen in Figure 5. The lactic acid content was higher in plates containing L. plantarum UM55 (approx. 30\% higher) than in L. buchneri UTAD104 ones, except for plates containing OD of 2.5. In these conditions, L. buchneri UTAD104 was confirmed as an acetic acid producer, with levels of this acid being significantly higher in plates containing this strain than in L. plantarum UM55 plates. Values were 6,5 and 4 times higher for $\mathrm{OD}$ of 1, 2.5 and 5, respectively.

\section{Discussion}

The use of $\mathrm{LAB}$ as biopreservatives against a vast range of food contaminants has already been described extensively in literature (Corsetti et al. 1998; Lavermicocca et al. 2000; Magnusson et al. 2003; Dalié et al. 2010; Gerez et al. 2010, 2013; Crowley et al. 2013; Oliveira et al. 2014). However, only a reduced number of works has focused on the inhibitory effect of LAB on the production of the mycotoxin OTA (Belkacem-Hanfi et al. 2014; Gerez et al. 2014). Also, the interaction between $P$. nordicum (a common ochratoxigenic contaminant of several food systems), LAB and their antifungal metabolites have not been studied so far. In this work, it was demonstrated that the CFS of $L$. plantarum UM55 and L. buchneri UTAD104 were able to inhibit $P$. nordicum MUM 08.16 

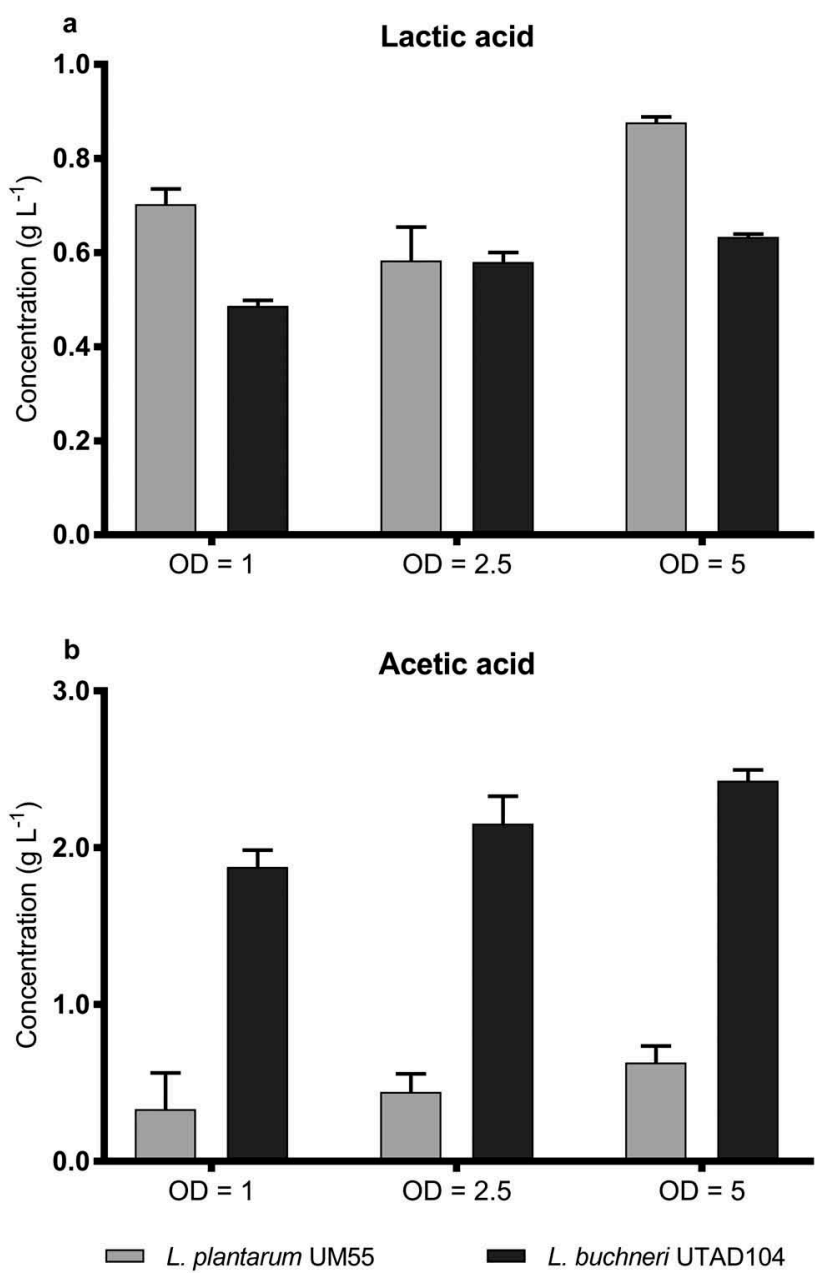

Figure 5. Concentration of lactic acid (A) and acetic acid (B) extracted from YES agar plates containing $10 \%$ of cells suspensions of L. buchneri UTAD104 and L. plantarum UM55 in PBS with OD values of $1,2.5$ and 5 .

growth by up to $20 \%$ and the production of OTA by approx. $60 \%$. It was also observed that the neutralisation of CFS $\mathrm{pH}$ led to the complete elimination of this effect, as reported by other authors (Gerez et al. 2009; Belkacem-Hanfi et al. 2014).

Since $\mathrm{pH}$ influenced the antifungal activity significantly, it was assumed that secreted organic acids were primarily responsible for the described antifungal effect. Organic acids produced by LAB exert their antimicrobial action after penetrating cell membranes in their undissociated form, leading to a drop in the intercellular $\mathrm{pH}$ and to the disruption of metabolic activities (Brul and Coote 1999). Besides the production of lactic acid, L. plantarum has been described as a producer of several organic acids with antimicrobial effect, such as acetic, propionic, phenyllactic, hydroxyphenyllactic, indole lactic, benzoic, coumaric, vanillic, butyric, formic, salicylic, succinic and azealic acids, among others (Niku-Paavola et al. 1999; Lavermicocca et al. 2000; Ström et al. 2002; Valerio et al. 2004; Broberg et al. 2007; Gerez et al. 2009; Prema et al. 2010; Dallagnol et al. 2011; Rizzello et al. 2011; Özcelik et al. 2016; Guimarães et al. 2018b), while L. buchneri as far as we are aware is mainly known for its capacity of producing lactic and acetic acids, and in some conditions propionic acid (Driehuis et al. 1999; Kung and Ranjit 2001; Johanningsmeier et al. 2012).

When analysing the organic acids profile of tested strains, L. plantarum UM55 was found to produce lactic acid, PLA, OH-PLA and ILA. Concentrations of lactic acid $\left(4.3 \mathrm{~g} \mathrm{~L}^{-1}\right)$, PLA $\left(74.8 \mathrm{mg} \mathrm{L}^{-1}\right)$ and $\mathrm{OH}$ PLA (30.8 $\mathrm{mg} \mathrm{L}^{-1}$ ) found in supernatants of $L$. plantarum UM55 were similar to those previously described by other authors (Valerio et al. 2004; Gerez et al. 2014). For example, Valerio et al. (2004) reported that strains of $L$. plantarum produced between 35 and $46 \mathrm{mg} \mathrm{L}^{-1}$ of PLA and 40 and $50 \mathrm{mg} \mathrm{L}^{-1}$ of OH-PLA. Concerning L. buchneri UTAD104, the production of lactic acid and PLA was identified but the method used in their quantification did not allow us to detect acetic acid, though L. buchneri is an obligate heterofermentative microorganism which produces, under aerobic as well as anaerobic conditions, both lactic acid and acetic acid (Heinl et al. 2012).

In the subsequent experiments, all of the mentioned acids have been found to inhibit to some degree the fungal growth of $P$. nordicum, and more substantially OTA production. Among all organic acids tested, acetic acid had the lowest $\mathrm{IC}_{50}$ and $\mathrm{IC}_{90}$ for fungal growth and $\mathrm{IC}_{90}$ for OTA and is probably primarily responsible for the strong antifungal ability of L. buchneri UTAD104 against $P$. nordicum MUM 08.16 (Danner et al. 2003). Acetic acid antiochratoxigenic activity appears to be caused by the inhibition of the fungal growth since low concentrations (0.1 and $0.25 \mathrm{mg} \mathrm{mL}^{-1}$ ) produce no inhibition whatsoever of both growth and OTA, intermediate concentrations inhibit growth and OTA similarly (approx. 15\% and 30\% of inhibition for 0.5 and $1 \mathrm{mg} \mathrm{mL}^{-1}$, respectively) and high concentrations inhibit the growth of $P$. nordicum entirely; therefore, no OTA could be produced. 
$\mathrm{IC}_{50}$ for OTA are relatively similar for all acids (approx. $1.5 \mathrm{mg} \mathrm{mL}^{-1}$ ) except for lactic acid, which $\mathrm{IC}_{50}$ is approx. 2 times higher $\left(2.9 \mathrm{mg} \mathrm{mL}^{-1}\right)$ than for the other acids. Although lactic acid was the least effective in inhibiting OTA production and the second least effective in inhibiting $P$. nordicum growth (after OH-PLA), lactic acid is probably the primary agent responsible for L. plantarum UM55 CFS inhibitory effects, since a concentration of $4 \mathrm{~g} \mathrm{~L}^{-1}$ inhibited the growth of P. nordicum by $32 \%$ and the production of OTA by $56 \%$, which corresponds approximately to the inhibitions obtained with $L$. plantarum UM55 CFS. Still, PLA, OH-PLA and ILA may also have been involved in the antifungal ability of this strain. Lavermicocca et al. (2003) studied the antifungal ability of PLA against moulds of bakery products and determined that a concentration of $7.5 \mathrm{mg} \mathrm{mL}^{-1}$ of PLA could inhibit by $90 \%$ the growth of fungal strains tested, which included Penicillium spp. This result is very similar to those obtained in the present study in which $8.4 \mathrm{mg} \mathrm{mL}^{-1}$ of PLA inhibits $90 \%$ of $P$. nordicum growth. Prema et al. (2010) also reported similar results, with minimum inhibitory concentration (MIC) values of PLA ranging from $6.5-12 \mathrm{mg} \mathrm{mL}^{-1}$. From our data, it can also be concluded that a relatively low concentration $\left(0.25 \mathrm{mg} \mathrm{mL}^{-1}\right)$ of PLA, OH-PLA and ILA result in a $20 \%$ inhibition of OTA production and that a concentration as low as $0.1 \mathrm{mg} \mathrm{mL}^{-1}$ of PLA allows a reduction of $12 \%$. Additionally, it has been mentioned that synergistic effects may explain the antifungal effect of some of these acids (Lavermicocca et al. 2003; Belguesmia et al. 2014). However, these synergisms remains unclear, and this type of interactions have not been proven rigorously for most of the compounds (Ström et al. 2002).

PLA and OH-PLA are compounds that are a part of phenylalanine and tyrosine biosynthesis, being involved in the mechanism that prevents phenylalanine accumulation. This amino acid either is transaminated to phenylpyruvic acid, which is a precursor of PLA, or hydrolysed to tyrosine, which is then converted to hydroxyphenylpyruvic acid and consequently metabolised to OH-PLA (Gummalla and Broadbent 2001). ILA is a result of successive transamination and dehydrogenation reactions in tryptophan catabolism (Gummalla and Broadbent 1999). The antimicrobial abilities of PLA, OH-
PLA and ILA have already been described previously (Narayanan 1976; Lavermicocca et al. 2000, 2003; Guimarães et al. 2018b), but this is the first time that their antifungal ability against an OTA producing fungus ( $P$. nordicum) has been characterised.

Concerning the experiments with cells from $L$. plantarum UM55 and L. buchneri UTAD104, an increase of the inhibitory effects was observed as expected with increasing concentration of cells. $L$. buchneri UTAD104 was significantly more effective in inhibiting fungal growth and OTA production than L. plantarum UM55 at all cell concentrations tested resulting in the absence of OTA in all the cases. The production of relatively high quantities of acetic acid is certainly responsible for the stronger inhibitory ability of $L$. buchneri UTAD104. As stated before, acetic acid has shown an inhibitory ability substantially superior to lactic acid, 27 times higher in the inhibition of OTA production.

Antifungal properties of these bacteria and their metabolites can make them a promising biological solution to reduce $P$. nordicum contamination and OTA levels in food and feed systems. Also, this knowledge can be used by LAB starter culture companies to select new strains with improved properties (higher secretion levels of acetic acid, PLA or ILA), improve their products and deliver solutions to control ochratoxigenic fungi, e.g. in silages, cheese and dry-sausages.

The use of L. buchneri strains has been extensively described for applications in silage (Filya 2003). Silage conservation is dependent on the absence of oxygen and maintenance of low $\mathrm{pH}$. The occurrence of natural $\mathrm{LAB}$ populations in crops is responsible for their acidification (McDonald 1981). Traditionally, homofermentative bacteria have been employed to achieve a faster production of lactic acid, to improve the effectiveness of the fermentation processes and increase dry matter recovery (Tabacco et al. 2011). However, aerobic spoilage increases the risk of proliferation of undesirable microorganisms (Driehuis and Elferink 2000). The deterioration of silage is triggered by the degradation of organic acids, generally by yeasts, which causes a rise in $\mathrm{pH}$ and an increase in temperature, leading to the proliferation of spoilage microorganisms, such as moulds (Elferink et al. 2000). The use of L. buchneri, an obligate 
heterofermentative $\mathrm{LAB}$, increases the content of acetic acid, keeps the $\mathrm{pH}$ at low values, and restrains the proliferation of pathogens, resulting in a 20 -fold increase in aerobic stability when compared with the untreated silages (Driehuis et al. 1999).

As mentioned before, acetic acid is a more potent antifungal metabolite than lactic acid (Ranjit and Kung 2000). Acetic acid has a higher pKa than lactic acid (4.75 and 3.86, respectively), which results in the stronger antimicrobial activity of acetic acid in low $\mathrm{pH}$ environments because a high proportion of acetic acid is in the undissociated state, and thus capable of penetrating the cell membrane of spoilage microorganisms. The production of acetic acid is probably the main reason why heterofermentative strains have a higher antimicrobial activity than homofermentative LAB (Holzer et al. 2003; Voulgari et al. 2010; Kharazian et al. 2017), thus explaining the results with the cells of L. buchneri UTAD104, which presented a higher inhibitory capacity than the cells of $L$. plantarum UM55. Still, some studies also suggest that L. buchneri can produce other metabolites with antifungal properties (Driehuis et al. 1999). For example, L. buchneri is capable of converting part of the lactic acid formed into acetic acid (Elferink et al. 2001), and during this process produce propionic acid and 1,2propanediol (Driehuis et al. 1999). Propionic acid can also contribute to the antifungal ability of this LAB species, according to Gerez et al. (2009). In our study, we were not able to detect propionic acid in CFS of $L$. buchneri UTAD104. Some authors have reported the ability of $L$. buchneri to inhibit fungal growth. Kharazian et al. (2017) have reported recently that L. buchneri was able to inhibit Fusarium verticillioides, Penicillium sp. and Verticillium dahlia. Still, only a few authors have described the inhibition of mycotoxin production by strains of L. buchneri. As far as we know, only Teller et al. (2012) reported that $L$. buchneri added to silage decreased the concentration of ZEA in silage made from unspoiled corn plants. Therefore, L. buchneri UTAD104 and other strains that may have a similar profile of organic acids can be of interest for silage inoculation, since we have proved that acetic acid is a strong inhibitor of the ochratoxigenic $P$. nordicum.

Besides silage, application of L. buchneri has been tested in bread to control moulds. In one study, the shelf life of bread prepared with sourdough incorporating $L$. buchneri and $L$. diolivorans was increased, when compared with bread prepared with traditional sourdough. This sourdough also demonstrated better inhibitory ability than traditional sourdough supplemented with acetate (Zhang et al. 2010). Le Lay et al. (2016) reported that L. buchneri isolates affected the growth of spoilage fungi from bakery products. In vitro, the isolates inhibited to some extent the growth of Aspergillus niger, Eurotium repens, $P$. corylophilum, Cladosporium sphaerospermum and Wallemia sebi. Additionally, in sourdough bread, some authors consider that acetic acid production improves the qualitative characteristics of the final product (Vernocchi et al. 2004) and is responsible for some of its typical flavours (Brandt 2007).

L. buchneri can also be beneficial in cheese ripening. Fröhlich-Wyder et al. (2013) determined that $L$. buchneri and L. parabuchneri isolated from cheese do not affect cheese quality or its flavours, but improve its chemical composition and eye formation by enhancing gas production. Several authors have reported the presence of OTA in different types of cheeses - blue cheese, hard cheese, traditional Italian cheese, Gorgonzola, Roquefort and white cheeses (Dall'Asta et al. 2008; Pattono et al. 2013; Benkerroum 2016; Decontardi et al. 2017). Others associate $P$. nordicum with the production of OTA in cheeses (Larsen et al. 2000). Despite the contaminations being relatively low, it is important to eliminate totally the presence of OTA in these products. This work proves that L. buchneri UTAD104, or other strains with similar organic acids profiles, could be beneficial to control $P$. nordicum growth and, consequently the production of OTA in this type of food.

Also, L. plantarum strains have been used broadly in several fermentation processes. In silage, L. plantarum has been employed in conjugation with other LAB, mainly L. buchneri (Weinberg et al. 2002; Filya 2003). In cheese, and similarly to what has been stated for L. buchneri, L. plantarum can be used as an adjunct culture in cheese formation and simultaneously as a biopreservative (Milesi et al. 2008; Cheong et al. 2014). Also in bread, L. plantarum was able to produce antifungal compounds during sourdough fermentation, retarding the growth of Fusarium species (Dal Bello et al. 2007). Again, the application of L. plantarum UM55 in these food 
products would be beneficial to control $P$. nordicum and OTA production, though it is a weaker inhibitor than L. buchneri UTAD104.

$P$. nordicum is also of particular concern in fermented meats such as dry-cured ham or dry-fermented sausages, because the environmental conditions in which the ripening takes place indiscriminately favours the growth of moulds (Sonjak et al. 2011). However, the growth of moulds in the surface of dry-cured meat is essential for the development of flavour and aromas, thus being a desirable event in many traditional products produced in Hungary, Italy, Spain, Greece, France, Austria, Belgium, among others (Berni 2014). Therefore, strategies in which some fungal growth is allowed, but the accumulation of OTA is prevented could be of great value in the production of traditional drycured meats. Several authors reported biopreservation methods for cured meats using microorganisms. For example, using yeasts such as Debaryomyces hansenii, positive results for inhibition in fungal growth and OTA production were obtained by Simoncini et al. (2014). Virgili et al. (2012) also reported Hyphopichia burtonii and Candida zeylanoides as effective inhibitors of $P$. nordicum and OTA production. Similarly, L. plantarum UM55 and/or L. buchneri UTAD104 could be applied in cured meats production processes as biopreservatives. The use of LAB is especially advantageous because they have a long history of use in fermented foods, but also because they can grow in a great variety of conditions; they do not need oxygen for growth, they are resistant to inhibition by carbon dioxide, nitrites and smoke and can grow at relatively high concentrations of salt (Egan 1983). The application of these bacteria can be an alternative solution to avoid the occurrence of OTA in these products without significantly reducing fungal growth and thus the beneficial characteristics that they confer to the final product, e.g. flavours and aromas (Iacumin et al. 2009). Pretreatments, where dry sausages were soaked in a solution of acetic acid, have also been described to prevent mould growth during the maturation of sausages (Holley 1981). In the present work, it is proved that the use of acetic and lactic acids are indeed beneficial for mould inhibition and most important for OTA production control since they have a considerable inhibitory effect in the production of this mycotoxin. Also, the ability of LAB strains to produce PLA, OHPLA and ILA can be relevant to the antifungal ability of the strains and should be taken into consideration when selecting strains for biopreservation proposes.

Application of these antifungal LAB strains could be made directly, either by dipping or spreading the $\mathrm{LAB}$ cultures onto food products or by incorporation into films and coatings that would enclose the food product. These films and coatings can improve the shelf life of the products, by providing a barrier against physical and mechanical damage, and by creating a controlled atmosphere around the food product. These films can also incorporate living microorganisms. Several works have already reported the incorporation of $\mathrm{LAB}$ into films and coatings with the goal of adding probiotic or antimicrobial properties. With the use of films and coatings, active compounds, such as organic acids, can be maintained at the surface of the food product at a suitable concentration to exert their antifungal ability and can also ensure a better stability and distribution of the microorganisms as they are entrapped in the film matrix, thus improving their antimicrobial activity (Guimarães et al. 2018a).

\section{Conclusions}

Fungal contamination is responsible for serious health problems, food waste and consequent economic losses. The use of LAB can be a suitable strategy to reduce these contaminations in a preservative-free approach. CFS of $L$. plantarum UM55 and L. buchneri UTAD104 have shown to inhibit $P$. nordicum growth as well as OTA production. Results indicate that the main substances responsible for the inhibitory activity were organic acids, particularly acetic acid, ILA, PLA, OH-PLA and lactic acid. When these compounds were tested individually, all exhibited the ability to inhibit the production of OTA and, to a lesser extent, the growth of P. nordicum. Acetic acid, ILA and PLA showed the stronger effects at the lowest concentrations. For $L$. plantarum UM55, lactic acid seems to be primarily responsible for the antifungal activity, since its concentration in CFS is substantially higher than for the other acids detected. For L. buchneri UTAD104, acetic acid seems to have the preponderant role in the fungal inhibition. The incorporation of living 
cells in the culture media resulted in a potent inhibition of $P$. nordicum. The addition of these LAB or LAB supernatants to food products, such as drycured meats, cheeses and bread, in a perspective of biopreservation, might be a suitable strategy to prevent $P$. nordicum contamination and the consequent production of OTA.

\section{Acknowledgements}

Ana Guimarães received support through grant SFRH/BD/ 103245/2014 from the Portuguese Foundation for Science and Technology (FCT). Luís Abrunhosa was supported by grant UMINHO/BPD/51/2015 from project UID/BIO/04469/2013 financed by FCT/MEC (OE). This study was supported by FCT under the scope of the strategic funding of UID/BIO/04469/2013 unit and COMPETE 2020 (POCI-01-0145-FEDER-006684); and of BioTecNorte operation (NORTE-01-0145-FEDER-000004) funded by European Regional Development Fund under the scope of Norte2020 - Programa Operacional Regional do Norte.

\section{Disclosure statement}

No potential conflict of interest was reported by the authors.

\section{Funding}

Ana Guimarães received support through grant SFRH/BD/ 103245/2014 from the Portuguese Foundation for Science and Technology (FCT). Luís Abrunhosa was supported by grant UMINHO/BPD/51/2015 from project UID/BIO/04469/ 2013 financed by FCT/MEC (OE). This study was supported by FCT under the scope of the strategic funding of UID/BIO/ 04469/2013 unit and COMPETE 2020 (POCI-01-0145FEDER-006684); and of BioTecNorte operation (NORTE01-0145-FEDER-000004) funded by European Regional Development Fund under the scope of Norte2020 Programa Operacional Regional do Norte.

\section{ORCID}

Ana Guimarães (D) http://orcid.org/0000-0002-2219-2803

Armando Venancio (D) http://orcid.org/0000-0002-0723-6134 Luís Abrunhosa (D) http://orcid.org/0000-0001-7234-4409

\section{References}

Ammor S, Tauveron G, Dufour E, Chevallier I. 2006. Antibacterial activity of lactic acid bacteria against spoilage and pathogenic bacteria isolated from the same meat smallscale facility: $1-$ screening and characterization of the antibacterial compounds. Food Control. 17(6):454-461.
Balouiri M, Sadiki M, Ibnsouda SK. 2016. Methods for in vitro evaluating antimicrobial activity: a review. J Pharm Anal. 6(2):71-79.

Battilani P, Pietri A, Giorni P, Formenti S, Bertuzzi T, Toscani T, Virgili R, Kozakiewicz Z. 2007. Penicillium populations in dry-cured ham manufacturing plants. J Food Protect. 70(4):975-980.

Belguesmia Y, Rabesona H, Mounier J, Pawtowsky A, Le Blay G, Barbier G, Haertlé T, Chobert J-M. 2014. Characterization of antifungal organic acids produced by Lactobacillus harbinensis K.V9.3.1Np immobilized in gellan-xanthan beads during batch fermentation. Food Control. 36(1):205-211.

Belkacem-Hanfi N, Fhoula I, Semmar N, Guesmi A, Perraud-Gaime I, Ouzari H-I, Boudabous A, Roussos S. 2014. Lactic acid bacteria against post-harvest moulds and ochratoxin A isolated from stored wheat. Biol Control. 76:52-59.

Benkerroum N. 2016. Mycotoxins in dairy products: a review. Int Dairy J. 62:63-75.

Berni E. 2014. Chapter 17, Molds. In: Toldrá F, Hui YH, Astiasaran I, Sebranek J, Talon R,editors. Handbook of fermented meat and poultry. Oxford (UK): Wiley; p. 147-153.

Bianchini A, Bullerman LB. 2009. Chapter 1, Biological control of molds and mycotoxins in foods. In: Appell M, Kendra DF, Trucksess MW, editors. Mycotoxin prevention and control in agriculture. Washington (DC): ACS Symposium Series, American Chemical Society; p. $1-16$.

Bogs C, Battilani P, Geisen R. 2006. Development of a molecular detection and differentiation system for ochratoxin A producing Penicillium species and its application to analyse the occurrence of Penicillium nordicum in cured meats. Int J Food Microbiol. 107(1):39-47.

Brandt MJ. 2007. Sourdough products for convenient use in baking. Food Microbiol. 24(2):161-164.

Broberg A, Jacobsson K, Strom K, Schnurer J. 2007. Metabolite profiles of lactic acid bacteria in grass silage. Appl Environ Microbiol. 73(17):5547-5552.

Brosnan B, Coffey A, Arendt EK, Furey A. 2014. The QuEChERS approach in a novel application for the identification of antifungal compounds produced by lactic acid bacteria cultures. Talanta. 129:364-373.

Brul S, Coote P. 1999. Preservative agents in foods mode of action and microbial resistance mechanisms. Int J Food Microbiol. 50(1-2):1-17.

Calado T, Fernández-Cruz ML, Cabo Verde S, Venâncio A, Abrunhosa L. 2018. Gamma irradiation effects on ochratoxin A: degradation, cytotoxicity and application in food. Food Chem. 240:463-471.

Cheong EYL, Sandhu A, Jayabalan J, Le TT K, Nhiep NT, Ho HT M, Zwielehner J, Bansal N, Turner MS. 2014 Isolation of lactic acid bacteria with antifungal activity against the common cheese spoilage mould Penicillium commune and their potential as biopreservatives in cheese. Food Control. 46:91-97. 
Corsetti A, Gobbetti M, Rossi J, Damiani P. 1998. Antimould activity of sourdough lactic acid bacteria: identification of a mixture of organic acids produced by Lactobacillus sanfrancisco CB1. Appl Microbiol Biotechnol. 50(2):253-256.

Crowley S, Mahony J, Van Sinderen D. 2013. Current perspectives on antifungal lactic acid bacteria as natural biopreservatives. Trends Food Sci Tech. 33(2):93-109.

Dal Bello F, Clarke CI, Ryan LAM, Ulmer H, Schober TJ, Ström K, Sjögren J, Van Sinderen D, Schnürer J, Arendt EK. 2007. Improvement of the quality and shelf life of wheat bread by fermentation with the antifungal strain Lactobacillus plantarum FST 1.7. J Cereal Sci. 45(3):309318.

Dalié DKD, Deschamps AM, Richard-Forget F. 2010. Lactic acid bacteria - potential for control of mould growth and mycotoxins: a review. Food Control. 21(4):370-380.

Dall'Asta C, De Dea Lindner J, Galaverna G, Dossena A, Neviani E, Marchelli R. 2008. The occurrence of ochratoxin A in blue cheese. Food Chem. 106(2):729-734.

Dallagnol AM, Catalán CAN, Mercado MI, Font De Valdez G, Rollán GC. 2011. Effect of biosynthetic intermediates and citrate on the phenyllactic and hydroxyphenyllactic acids production by Lactobacillus plantarum CRL 778. J Appl Microbiol. 111(6):1447-1455.

Danner H, Holzer M, Mayrhuber E, Braun R. 2003. Acetic acid increases stability of silage under aerobic conditions. Appl Environ Microbiol. 69(1):562-567.

Decontardi S, Mauro A, Lima N, Battilani P. 2017. Survey of Penicillia associated with Italian grana cheese. Int J Food Microbiol. 246:25-31.

Driehuis F, Elferink SJWHO. 2000. The impact of the quality of silage on animal health and food safety: a review. Vet Q. 22(4):212-216.

Driehuis F, Elferink SJWHO, Spoelstra SF. 1999. Anaerobic lactic acid degradation during ensilage of whole crop maize inoculated with Lactobacillus buchneri inhibits yeast growth and improves aerobic stability. J Appl Microbiol. 87(4):583-594.

Egan AF. 1983. Lactic acid bacteria of meat and meat products. Antonie Van Leeuwenhoek. 49(3):327-336.

Elferink SJWHO, Driehuis F, Gottschal JC, Spoelstra SF 2000. Silage fermentation processes and their manipulation. FAO Plant Production and Protection Papers. 17-30.

Elferink SJWHO, Krooneman J, Gottschal JC, Spoelstra SF, Faber F, Driehuis F. 2001. Anaerobic conversion of lactic acid to acetic acid and 1, 2-propanediol by Lactobacillus buchneri. Appl Environ Microbiol. 67(1):125-132.

[FAO/WHO] Food and Agriculture Organization of the United Nations/World Health Organization. 2002. Evaluation of certain mycotoxins in food (Fifty-sixth report of the Joint FAO/WHO Expert Committee on Food Additives). WHO Technical Report Series. 906.

Filya I. 2003. The effect of Lactobacillus buchneri and Lactobacillus plantarum on the fermentation, aerobic stability, and ruminal degradability of low dry matter corn and sorghum silages. J Dairy Sci. 86(11):3575-3581.
Fröhlich-Wyder M-T, Guggisberg D, Badertscher R, Wechsler D, Wittwer A, Irmler S. 2013. The effect of Lactobacillus buchneri and Lactobacillus parabuchneri on the eye formation of semi-hard cheese. Int Dairy J. 33 (2):120-128.

Gerez CL, Carbajo MS, Rollan G, Torres Leal G, Font De Valdez G. 2010. Inhibition of citrus fungal pathogens by using lactic acid bacteria. J Food Sci. 75(6):M354-359.

Gerez CL, Dallagnol A, Ponsone L, Chulze S, Font De Valdez G. 2014. Ochratoxin A production by Aspergillus niger: effect of water activity and a biopreserver formulated with Lactobacillus plantarum CRL 778. Food Control. 45:115119.

Gerez CL, Torino MI, Rollán G, Font De Valdez G. 2009. Prevention of bread mould spoilage by using lactic acid bacteria with antifungal properties. Food Control. 20 (2):144-148.

Gerez CL, Torres MJ, Font De Valdez G, Rollán G. 2013. Control of spoilage fungi by lactic acid bacteria. Biol Control. 64(3):231-237.

Guimarães A, Abrunhosa L, Pastrana Lorenzo M, Cerqueira Miguel A. 2018a. Edible films and coatings as carriers of living microorganisms: a new strategy towards biopreservation and healthier foods. Compr Rev Food Sci Food Saf. 17(3):594-614.

Guimarães A, Santiago A, Teixeira JA, Venâncio A, Abrunhosa L. 2018b. Anti-aflatoxigenic effect of organic acids produced by Lactobacillus plantarum. Int J Food Microbiol. 264:31-38.

Gummalla S, Broadbent JR. 1999. Tryptophan catabolism by Lactobacillus casei and Lactobacillus helveticus cheese flavor adjuncts. J Dairy Sci. 82(10):2070-2077.

Gummalla S, Broadbent JR. 2001. Tyrosine and phenylalanine catabolism by Lactobacillus cheese flavor adjuncts. J Dairy Sci. 84(5):1011-1019.

Heinl S, Wibberg D, Eikmeyer F, Szczepanowski R, Blom J, Linke B, Goesmann A, Grabherr R, Schwab H, Pühler A, et al. 2012. Insights into the completely annotated genome of Lactobacillus buchneri CD034, a strain isolated from stable grass silage. J Biotechnol. 161(2):153-166.

Höhler D. 1998. Ochratoxin A in food and feed: occurrence, legislation and mode of action. Eur J Nutr. 37(1):2-12.

Holley RA. 1981. Prevention of surface mold growth on Italian dry sausage by natamycin and potassium sorbate. Appl Environ Microbiol. 41(2):422-429.

Holzer M, Mayrhuber E, Danner H, Braun R. 2003. The role of Lactobacillus buchneri in forage preservation. Trends Biotechnol. 21(6):282-287.

Iacumin L, Chiesa L, Boscolo D, Manzano M, Cantoni C, Orlic S, Comi G. 2009. Moulds and ochratoxin A on surfaces of artisanal and industrial dry sausages. Food Microbiol. 26(1):65-70.

[IARC] International Agency for Research on Cancer. 1993. Some naturally occurring substances: food items and constituents, heterocyclic aromatic amines and mycotoxins. In: IARC, editor. IARC monographs on the evaluation of 
carcinogenic risks to Humans. Lyon (France): WHO Press; p. $489-521$.

Johanningsmeier SD, Franco W, Perez-Diaz I, McFeeters RF. 2012. Influence of sodium chloride, $\mathrm{pH}$, and lactic acid bacteria on anaerobic lactic acid utilization during fermented cucumber spoilage. J Food Sci. 77(7):M397-M404.

Kharazian ZA, Salehi Jouzani G, Aghdasi M, Khorvash M, Zamani M, Mohammadzadeh H. 2017. Biocontrol potential of Lactobacillus strains isolated from corn silages against some plant pathogenic fungi. Biol Control. 110:33-43.

Kung L, Ranjit NK. 2001. The effect of Lactobacillus buchneri and other additives on the fermentation and aerobic stability of barley silage. J Dairy Sci. 84(5):1149-1155.

Larsen TO, Smedsgaard J, Lund F, Frisvad JC, Gareis M. 2000. Chemical characterisation of cheese associated fungi. Mycotoxin Res. 16(1):109.

Lavermicocca P, Valerio F, Evidente A, Lazzaroni S, Corsetti A, Gobbetti M. 2000. Purification and characterization of novel antifungal compounds from the sourdough Lactobacillus plantarum strain 21B. Appl Environ Microbiol. 66(9):40844090.

Lavermicocca P, Valerio F, Visconti A. 2003. Antifungal activity of phenyllactic acid against molds isolated from bakery products. Appl Environ Microbiol. 69(1):634-640.

Le Lay C, Mounier J, Vasseur V, Weill A, Le Blay G, Barbier G, Coton E. 2016. In vitro and in situ screening of lactic acid bacteria and propionibacteria antifungal activities against bakery product spoilage molds. Food Control. 60:247-255.

Lund F, Frisvad JC. 2003. Penicillium verrucosum in wheat and barley indicates presence of ochratoxin A. J Appl Microbiol. 95(5):1117-1123.

Magnusson J, Schnurer J. 2001. Lactobacillus coryniformis subsp. coryniformis strain Si3 produces a broad-spectrum proteinaceous antifungal compound. Appl Environ Microbiol. 67(1):1-5.

Magnusson J, Ström K, Roos S, Sjögren J, Schnürer J. 2003. Broad and complex antifungal activity among environmental isolates of lactic acid bacteria. FEMS Microbiol Lett. 219(1):129-135.

McDonald P. 1981. The biochemistry of silage. Chichester, UK: John Wiley \& Sons, Ltd.

Milesi MM, McSweeney PLH, Hynes ER. 2008. Viability and contribution to proteolysis of an adjunct culture of Lactobacillus plantarum in two model cheese systems: cheddar cheese-type and soft-cheese type. J Appl Microbiol. 105(3):884-892.

Naidu AS, Bidlack WR, Clemens RA. 1999. Probiotic spectra of lactic acid bacteria (LAB). Crit Rev Food Sci Nutr. 39 (1):13-126.

Narayanan TKGRR. 1976. Beta-Indoleethanol and BetaIndolelactic acid production by Candida Species: their antibacterial and antoantibiotic action. Antimicrob Agents Chemother. 9:375-380.

Niku-Paavola ML, Laitila A, Mattila-Sandholm T, Haikara A. 1999. New types of antimicrobial compounds produced by Lactobacillus plantarum. J Appl Microbiol. 86(1):29-35.
Oliveira PM, Brosnan B, Jacob F, Furey A, Coffey A, Zannini E, Arendt EK. 2015. Lactic acid bacteria bioprotection applied to the malting process. Part II: substrate impact and mycotoxin reduction. Food Control. 51:444-452.

Oliveira PM, Zannini E, Arendt EK. 2014. Cereal fungal infection, mycotoxins, and lactic acid bacteria mediated bioprotection: from crop farming to cereal products. Food Microbiol. 37:78-95.

Özcelik S, Kuley E, Özogul F. 2016. Formation of lactic, acetic, succinic, propionic, formic and butyric acid by lactic acid bacteria. LWT-Food Sci Technol. 73:536-542.

Pattono D, Grosso A, Stocco PP, Pazzi M, Zeppa G. 2013. Survey of the presence of patulin and ochratoxin A in traditional semi-hard cheeses. Food Control. 33(1):5457.

Petzinger E, Weidenbach A. 2002. Mycotoxins in the food chain: the role of ochratoxins. Livest Prod Sci. 76(3):245-250.

Pitt JI, Hocking AD. 2009. Fungi and food spoilage. 3th ed. New York (USA): Springer.

Prema P, Smila D, Palavesam A, Immanuel G. 2010. Production and characterization of an antifungal compound (3-phenyllactic Acid) produced by Lactobacillus plantarum strain. Food Bioprocess Technol. 3(3):379-386. Ranjit NK, Kung L. 2000. The effect of Lactobacillus buchneri, Lactobacillus plantarum, or a chemical preservative on the fermentation and aerobic stability of corn silage. J Dairy Sci. 83(3):526-535.

Rizzello CG, Cassone A, Coda R, Gobbetti M. 2011. Antifungal activity of sourdough fermented wheat germ used as an ingredient for bread making. Food Chem. 127 (3):952-959.

Rouse S, Harnett D, Vaughan A, Sinderen D. 2008. Lactic acid bacteria with potential to eliminate fungal spoilage in foods. J Appl Microbiol. 104(3):915-923.

Sangmanee P, Hongpattarakere T. 2014. Inhibitory of multiple antifungal components produced by Lactobacillus plantarum K35 on growth, aflatoxin production and ultrastructure alterations of Aspergillus flavus and Aspergillus parasiticus. Food Control. 40(1):224-233.

Simoncini N, Virgili R, Spadola G, Battilani P. 2014. Autochthonous yeasts as potential biocontrol agents in dry-cured meat products. Food Control. 46:160-167.

Sjögren J, Magnusson J, Broberg A, Schnurer J, Kenne L. 2003. Antifungal 3-Hydroxy Fatty Acids from Lactobacillus plantarum MiLAB 14. Appl Environ Microbiol. 69(12):7554-7557.

Sonjak S, Ličen M, Frisvad JC, Gunde-Cimerman N. 2011. The mycobiota of three dry-cured meat products from Slovenia. Food Microbiol. 28(3):373-376.

Ström K, Sjögren J, Broberg A, Schnürer J. 2002. Lactobacillus plantarum MiLAB 393 produces the antifungal cyclic dipeptides cyclo(l-Phe-1-Pro) and cyclo(l-Phetrans-4-OH-1-Pro) and 3-phenyllactic acid. Appl Environ Microbiol. 68(9):4322-4327.

Tabacco E, Piano S, Revello-Chion A, Borreani G. 2011. Effect of Lactobacillus buchneri LN4637 and Lactobacillus buchneri LN40177 on the aerobic stability, fermentation 
products, and microbial populations of corn silage under farm conditions. J Dairy Sci. 94(11):5589-5598.

Teller RS, Schmidt RJ, Whitlow LW, Kung L. 2012. Effect of physical damage to ears of corn before harvest and treatment with various additives on the concentration of mycotoxins, silage fermentation, and aerobic stability of corn silage. J Dairy Sci. 95(3):1428-1436.

Valerio F, Lavermicocca P, Pascale M, Visconti A. 2004. Production of phenyllactic acid by lactic acid bacteria: an approach to the selection of strains contributing to food quality and preservation. FEMS Microbiol Lett. 233(2):289295.

Vernocchi P, Valmorri S, Gatto V, Torriani S, Gianotti A, Suzzi G, Guerzoni ME, Gardini F. 2004. A survey on yeast microbiota associated with an Italian traditional sweet-leavened baked good fermentation. Food Res Int. 37(5):469-476.

Virgili R, Simoncini N, Toscani T, Camardo Leggieri M, Formenti S, Battilani P. 2012. Biocontrol of Penicillium nordicum growth and ochratoxin A production by native yeasts of dry cured ham. Toxins. 4(2):68-82.

Voulgari K, Hatzikamari M, Delepoglou A, Georgakopoulos P, Litopoulou-Tzanetaki E, Tzanetakis N. 2010. Antifungal activity of non-starter lactic acid bacteria isolates from dairy products. Food Control. 21(2):136-142.

Weinberg ZG, Ashbell G, Hen Y, Azrieli A, Szakacs G, Filya I. 2002. Ensiling whole-crop wheat and corn in large containers with Lactobacillus plantarum and Lactobacillus buchneri. J Ind Microbiol Biotechnol. 28(1):7-11.

Yang EJ, Chang HC. 2010. Purification of a new antifungal compound produced by Lactobacillus plantarum AF1 isolated from kimchi. Int J Food Microbiol. 139(12):56-63.

Zhang C, Brandt MJ, Schwab C, Gänzle MG. 2010. Propionic acid production by cofermentation of Lactobacillus buchneri and Lactobacillus diolivorans in sourdough. Food Microbiol. 27(3):390-395. 